\title{
Administração e progresso
}

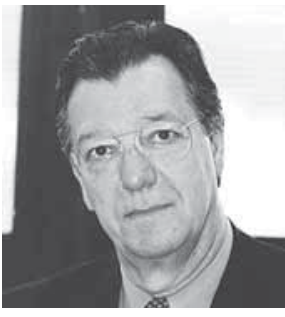

Carlos Osmar Bertero

FGVEAESP

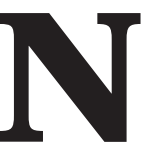

ossa cultura e nossas vidas são permeadas pela idéia de progresso.

0 horizonte é sempre visto como guardando coisas melhores e superiores às que atualmente possuímos. A economia deve crescer de maneira sustentada. Os excluídos deverão ser incluídos. A ignorância deverá ser eliminada e o conhecimento se expandirá levando luz a realidades que permanecem envoltas em trevas.

Assim, uma maneira de ler a história é nos satisfazermos com ar triunfante e ver quanto a humanidade caminhou e como hoje somos melhores do que éramos no passado. 0 deleite é particularmente intenso quando nos voltamos para realizações tecnológicas: ver o quanto avançamos em transportes, comunicações, eletrônica, bioquímica, informações etc.

E se olharmos para a administração? Qual visão de progresso poderá emergir quando falamos de administração?

A administração progrediu mais em algumas áreas do que em outras. Diria que a função de controle caminhou muito. Se atentarmos para o uso do tempo por administradores, ve mos que boa parte dele é dedicada a controlar pessoas, materiais, produtos, fluxos diversos e o próprio tempo. Aqui encontramos o uso de técnicas desenvolvidas em outras áreas com grande proficiência.

Desde o desenvolvimento da contabilidade de custos, até descrições de cargos, cronogramas que se construíram ao longo das décadas usando várias técnicas, e, atualmente, a tecnologia da informação com o apoio das telecomunicações e, no apogeu, o Balanced ScoreCard.

A coordenação foi outra função que caminhou quase que devido às mesmas razões e usando os mesmos instrumentos e técnicas. De fato, sem avanços em coordenação e controle não seria possível administrar as imensas organizações, tanto públicas como de negócios que hoje possuímos.

Talvez as buscas por progresso se tornem mais difíceis quando nos voltamos para áreas como gestão estratégica e de pessoas. Se indagarmos como se formulavam estratégias há al gumas décadas e no que diferem daquilo que hoje se faz, talvez o "progresso" não seja tão evidente e tão marcante.

Modelos de gestão estratégica foram criados, mas mais no sentido de monitorar a execução ou implementação e menos, muito menos, para descortinar como estratégias se formulam ou podem ser formuladas. A área ainda permanece em boa medida "terra incógnita". Com relação à gestão de pessoas, há espaço para que vejamos enormes ambivalências. Talvez porque esta seja uma das áreas mais carregadas de carga valorativa dentre as diversas áreas funcionais. Mesmo assim, quando se olham as condições de trabal ho atuais e o passado não há como negar que houve melhorias. 